Karolina Walczak

Uniwersytet Łódzki

Wydział Nauk o Wychowaniu

Pracownia Pedagogiki Specjalnej

91-433 Łódź, ul. Smugowa 10/12

\title{
Bullying w środowisku społecznym szkoły i więzienia
}

\section{Streszczenie}

Artykuł stanowi teoretyczne ujęcie problematyki bullyingu, uwzględniając specyfikę instytucji, w której do niego dochodzi. Nie ma już żadnych wątpliwości, że bullying w środowisku szkolnym i zawodowym jest znaczącym problemem, opisywanym w kontekście przyczyn i konsekwencji indywidualnych oraz społecznych. Wypracowano także skuteczne działania profilaktyczne i programy interwencyjne pozwalające $\mathrm{w}$ dużej mierze niwelować przemoc rówieśniczą o charakterze bullyingu w tych środowiskach. Obecne badania nad bullyingiem koncentrują się jednak na zgłębianiu problematyki w odniesieniu do środowiska więziennego i różnicowaniu zarówno w kontekście definicyjnym, jak i wyjaśniających go ujęć teoretycznych.

Słowa kluczowe: bullying w szkole, bullying w więzieniu.

Zainteresowanie teoretyków i praktyków problematyką bullyingu ma już ponad czterdziestoletnią tradycję. Uwaga badaczy koncentrowała się podczas tego okresu na wielu aspektach tego zjawiska, zaczynając od prób zdefiniowania pojęcia, opracowania programów naprawczych, poprzez dokonanie charakterystyki typów bullyingu, ról uczestników przemocy rówieśniczej o charakterze bullyingu. Obecnie badania zostały pogłębione o bullying realizowany przy wykorzystaniu nowych technologii komunikacyjnych (cyberbullying i agresja elektroniczna).

\section{Definiowanie pojęcia „bullying”}

Analizując termin „bullying”, możemy napotkać na różnorodne jego definicje w zależności od przyjęcia określonego nazewnictwa w danym kraju oraz miejsca, w którym dochodzi do dręczenia, tj. środowisko szkolne - rówieśnicze, 
środowisko pracy, środowisko więzienne. Jednym z pierwszych badaczy zjawiska dręczenia uczniów był szwedzki lekarz P. P. Heinemann, który użył terminu „mobbing” do zdefiniowania problemu przemocy grupowej wydarzającej się nagle, skierowanej przeciwko jednostce (Hirigoyen, 2003). Definicja ta okazała się jednak dla naukowców definicją nieprecyzyjnie wyjaśniającą eksponowane zachowanie i niekompletną. D. Olweus, formułując definicję „bullyingu”, dokonuje jego diagnozy na podstawie trzech kryteriów, które muszą być spełnione, aby określone zachowanie można było nazwać bullyingiem. Są to intencjonalne, negatywne zachowania jednostki lub grupy mające na celu krzywdzenie, napastowanie jednostki lub grupy, które wydarzają się nagle, nieoczekiwanie, są powtarzane i trwają dłuższy czas, w których wyraźnie zaznacza się nierównowaga sil między sprawcą (bully) i ofiarą (victim) (Smith i in., 2002).

Definicję podkreślającą powyższą triadę podają także W. Craig i D. Pepler, określając bullying jako „negatywne fizyczne lub werbalne działania, które charakteryzują się wrogą intencją, powodują negatywne emocje u ofiar, są powtarzalne w czasie oraz charakteryzują się różnicą sił pomiędzy sprawcami a ofiarą" (Pyżalski, 2012).

Również polski badacz J. Surzykiewicz (2000) wymienia wśród wyznaczników bullyingu określone cechy, takie jak: jednostronność wyrządzanej ofierze szkody (brak równego rozkładu sił), rozciągłość w czasie i powtarzalność.

M. Kliś (2000), definiując zjawisko bullyingu, wymienia trzy jego cechy, równocześnie podkreślając brak winy ze strony ofiary. Ujmuje go jako negatywne działania, powtarzające się przez dłuższy czas, podczas których występuje nierównomierny rozkład sił między znęcającym się a ofiarą, a wszelkie formy dręczenia nie są prowokowane przez ofiarę.

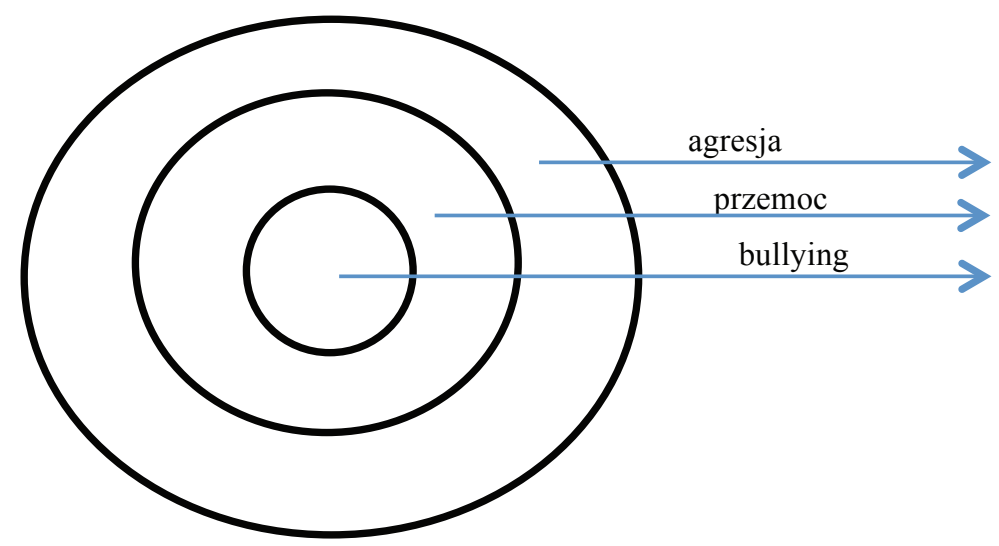

Rysunek 1. Relacje między polami znaczeniowymi bullyingu, przemocy i agresji Źródło: J. Pyżalski, Agresja elektroniczna i cyberbullying jako nowe ryzykowne zachowania młodzieży, Impuls, Kraków 2012, s. 111 
Można zaobserwować, że wielu autorów znacząco podkreśla intencjonalność, powtarzalność, nierównowagę sił między głównymi uczestnikami bullyingu, jako jego charakterystyczne właściwości. W związku z powyższym obrona przed atakiem jest znacznie utrudniona, ofiara podejmuje próby obrony, choć często okazuje się, że jest ona nieskuteczna.

Warto zaznaczyć także fakt częstego utożsamiania „bullyingu” z agresją, co jest znaczącą nieprawidłowością, gdyż bullying jest pojęciem o znacznie szerszym zakresie niż agresja.

I mimo że każde działanie bullyingowe wchodzi w zakres pojęciowy agresji, to nie każde agresywne zachowanie można określić jako bullying. Powinno ono bowiem spełniać wymienione powyżej warunki.

Jak podkreśla J. Pyżalski (2012), między pojęciami agresji, przemocy i bullyingu występuje hierarchiczny stosunek, w którym najwęższy zakres przypisuje się bullyingowi, a najobszerniejszy agresji (rysunek 1).

Analizując zjawisko bullyingu w szkole można zaobserwować różnorodność form, jakie przyjmuje. Mowa tu o negatywnych działaniach o charakterze fizycznym i psychicznym. Jawne niegdyś konflikty, spory i kłótnie między uczniami przybierają obecnie formy subtelnych, wyrafinowanych prześladowań, ukrytych ataków, które trudno zaobserwować. Najczęstszym z typów prześladowania uczniów są: przezywanie, bezpośrednie ataki fizyczne, wykluczanie z grupy, zastraszanie czy poniżanie (Hennesey, Guerin, 2004).

H. Hoel, C. Rayner, C. L. Cooper (Smith i in., 2003) wśród form bullyingu wymieniają:

- fizyczne i werbalne/słowne - bicie, popychanie, zastraszanie, obrażanie, znieważanie, plotkowanie, ośmieszanie, przezywanie;

- pośrednie i relacyjne - rozsiewanie plotek i pogłosek, wykluczanie z grupy, sprzysięganie się przeciw komuś, odchodzenie, gdy ofiara podchodzi do grupy.

Badacze podają, że znaczącą przewagę tych ostatnich zauważa się w okresie adolescencji i w dorosłym życiu, najczęściej w kontaktach w pracy.

Odmienne spojrzenie na zjawisko bullyingu prezentują badania prowadzone w środowisku więziennym (Connel i Farrington, 1999; Ireland i Acher, 1996; Ireland 2008). Warto przyjrzeć się temu obszarowi z uwagi na specyfikę placówki resocjalizacyjnej. Obecnie odchodzi się od jednoznacznego rozumienia bullyingu w szkole i w więzieniu, co w początkowej fazie badań nad bullyingiem w więzieniu można było obserwować. Brak różnicowania definicyjnego spotkał się więc z krytyką wielu naukowców.

Definiując problem bullyingu w więzieniu, odrzuca się kryteria diagnostyczne przyjęte w tradycyjnym bullyingu, takie jak powtarzalność, intencjonalność i nierównowagę sił między uczestnikami działań bullyingowych (Monks i in., 2012).

J. L. Ireland, J. Archer, Ch. L. Power (2007) podają, że działanie może być traktowane jako bullying, jeśli działania wydarzają się co najmniej raz w tygodniu i jednostka jest narażona zarówno na atak bezpośredni, jak i pośredni ze strony 
tego samego lub innego sprawcy. Ważnym kryterium jest tutaj strach przed dręczeniem odczuwany przez ofiary, a nie samo działanie. Czynnikiem różnicującym tradycyjny bullying od bullyingu więziennego jest także brak widocznej, jawnej nierównowagi sił między sprawcą i ofiarą.

„Pojedyncze akty agresji mogą być traktowane jako bullying, zwłaszcza gdy są poważne i kiedy osoba wierzy, że jest narażona na przemoc w przyszłości ze strony tego samego sprawcy lub innych, bądź boi się tego. Zdarzenie może zostać zaklasyfikowane jako bullying, jeśli ofiara jest przekonana, że była celem agresji, niezależnie od intencji sprawcy. O bullyingu możemy mówić także wtedy, kiedy nierównowaga sił między mobberem, a jego ofiarą jest domniemana, acz nie od razu oczywista" (Monks, Coyne, 2012, s. 155).

J. L. Ireland, prowadząc badania nad bullyingiem więziennym, przy wykorzystaniu Listy Bezpośrednich i Pośrednich Zachowań Więźniów DIPC, pytał więźniów o przejawianie i doświadczanie określonych zachowań. 25 pytań dotyczyło doświadczania przemocy, a 26 stosowania przemocy w ciągu ostatnich sześciu miesięcy. Respondenci odpowiadali na pytania, odnosząc się do pięciostopniowej skali, określającej częstotliwość. Na podstawie odpowiedzi dokonano podziału uczestników badania na „czystych sprawców”, „,zyste ofiary”, „sprawców - ofiary” oraz „niezaangażowanych”. Największą grupą okazali się sprawcy - ofiary (więźniowie, którzy zgłaszali zarówno zachowania stosowane przez sprawców, jak i ofiary). Stanowili oni powyżej $40 \%$ badanych. Przynależność do tej grupy uczestników bullyingu więziennego została określona jako zachowanie funkcjonalne, gdyż stosowanie przemocy jest reakcją na negatywne działania innych więźniów. Takie zachowanie zapewni więźniom większy nadzór ze strony strażników, więźniowie posiadają bowiem etykietkę ,zagrażających/niebezpiecznych". Stosowanie działań o charakterze bullyingu może także ochronić ich przed stosowaniem przemocy wobec nich samych. Ponadto jest także sposobem na czasowe odosobnienie więźnia, co choć na krótki czas daje poczucie bezpieczeństwa i chroni przed byciem ofiarą ze strony współwięźniów. Więźniowie, dbając o własną pozycję w grupie, nie dopuszczają także do przypisania im etykietki osoby uległej i słabej.

Powyższe informacje, poparte wynikami badań różnych autorów, potwierdzają tezę, że o bullyingu w więzieniu świadczy samo poczucie strachu przed przyjęciem roli ofiary. Świadczą o tym chociażby zachowania uczestników z grupy sprawców - ofiar. Jak podaje J. L. Ireland, bullying może być w tym przypadku traktowany jako zachowanie przystosowawcze i niekoniecznie powinien być traktowany jako przejaw braku umiejętności właściwego zachowania. Strach bowiem motywuje więźniów do podejmowania określonych zachowań negatywnych wobec innych (Monks, Coyne, 2012).

Podsumowując rozważania dotyczące definiowania bullyingu uwzględniające kontekst środowiskowy, a co za tym idzie różnice w jego rozumieniu, warto przytoczyć okresy, jakie zarysowały się w badaniach nad bullyingiem. 
Analizując badania bullyingu na przestrzeni lat, można wyróżnić cztery ich etapy (Monks, Coyne, 2012).

Etap pierwszy obejmował lata 1970-1988, podczas których pionier badań nad bullyingiem w szkole D. Olweus opracował pierwszą definicję bullyingu, różnicując go od opisywanego wcześniej przez P. P. Heinemanna zjawiska mobbingu. D. Olweus rozpatrywał bullying nie tylko w kontekście działań grupowych skierowanych przeciw jednostce (jak to miało miejsce wcześniej), ale podkreślał także rolę systematycznych, intencjonalnych negatywnych działań jednostki skierowanych przeciw jednostce, mających na celu wyrządzenie krzywdy, które wydarzają się nagle i są powtarzalne oraz charakteryzują się nierównowagą siły między uczestnikami. Wyróżnił zatem trzy kryteria definicyjne charakterystyczne dla bullyingu. W tym okresie opracowano także pierwszy program interwencyjno-prewencyjny dla szkół. W wyniku przeprowadzonej w latach 80. ewaluacji podejmowanych działań w obszarze profilaktyki bullyingu dowiedziono wysoką skuteczność programu antybullyingowego, gdyż zjawisko bullyingu zostało zredukowane o $50 \%$.

Druga faza badań nad bullyingiem koncentrowała się na włączeniu w zakres pojęciowy spektrum zachowań mających charakter relacyjny (np. sprzysięganie się przeciw komuś, odseparowanie od grupy). Badania te przybrały charakter międzynarodowy i wykorzystywały już nie tylko kwestionariusze, ale metodę socjometryczną, która dawała możliwość wskazania ról innych osób w bullyingu.

Kolejna faza badań nad bullyingiem obejmuje lata 1990-2004. Badania przybrały w tym czasie formę dużego projektu badawczego, koncentrującego się na wieloaspektowym badaniu zagadnienia bullyingu. Zgłębiano temat wiktymizacji oraz diagnozy pod kątem ról, jakie odgrywają uczestnicy bullyingu.

Ostatnia faza badań odnosi się do bullyingu z wykorzystaniem nowoczesnych technologii informacyjnych tzw. cyberbullyingu i agresji elektronicznej. Zagadnienie to doczekało się także polskich opracowań (Kowalski i in., 2008, Pyżalski, 2010; 2012).

\section{Teoretyczne i empiryczne podejście do problematyki bullyingu}

Analizując dostępną literaturę odnoszącą się do zjawiska bullyingu, możemy napotkać różne podejścia teoretyczne wyjaśniające bullying. Niektóre z nich zostały wsparte badaniami, jednak istnieje także szereg niepotwierdzonych empirycznie podejść teoretycznych, opisujących problem bullyingu. W literaturze napotykamy na generalne teorie wyjaśniające zjawisko bullyingu bez różnicowania go ze względu na środowisko, w jakim do niego dochodzi, jednak można również spotkać te odnoszące się jedynie do bullyingu w więzieniu. Podczas przeglądu publikacji traktujących o problematyce bullyingu obserwuje się brak 
jednoznacznego podejścia wyjaśniającego uczestniczenie w bullyingu, a co się $\mathrm{z}$ tym wiąże brak silnego osadzenia $\mathrm{w}$ teorii.

Ze względu na powyższe czynniki badania nad bullyingiem, zarówno w środowisku szkolnym, jak i więziennym, poddawane są stałej krytyce. Do niejednoznacznego ulokowania badań w teorii mogła przyczynić się zbyt duża koncentracja badaczy na samym definiowaniu zjawiska bullyingu, a nie wyjaśnianiu jego podłoża. Obecnie przyjmuje się perspektywę indywidualną, społeczną i ekologiczną w wyjaśnianiu problematyki bullyingu.

Badania dotyczące podłoża zachowań przemocowych o charakterze bullyingu wskazują na duże znaczenie środowisk wychowawczych w kształtowaniu się określonych predyspozycji do przyjmowania roli sprawcy lub ofiary. Sprawcami bullyingu zostają zazwyczaj dzieci wychowywane przez autorytarnych rodziców, traktujących dzieci z dużym dystansem i stosujących kary fizyczne. Relacje rodzicielskie często pozbawione są ciepła, bliskości oraz przepełnione konfliktowością (Swearer i in., 2010; Pyżalski, 2012). Natomiast wśród charakterystycznych cech rodzin, w których wychowują się ofiary bullyingu autorzy wymieniają często zmienne społeczno-ekonomiczne, takie jak samotne macierzyństwo, niski status ekonomiczny rodziny (Swearer i in., 2010).

Rodzice modelują postawy dzieci i kształtują umiejętności radzenia sobie w sytuacjach trudnych, stanowią przykład uczący radzenia sobie z negatywnymi emocjami oraz rozwiązywania sytuacji konfliktowych. „Niestety dzieci często natrafiają na wzory, które są dalekie od ideału i uczą się postaw agresywnych, nie potrafią identyfikować emocji, ani panować nad nimi, mają ograniczony zakres reakcji emocjonalnych na sytuacje wywołujące stres (na przykład gniew)" (Swearer $\mathrm{i}$ in., 2010, s. 44).

Analizując powyższe informacje, można odwołać się do kilku teorii wyjaśniających bullying. Odnosząc się do teorii społecznego uczenia się zachowań A. Bandury, poprzez modelowanie możemy wyjaśnić zaangażowanie w bullying jako wynik obserwacji zachowań i postaw rodzicielskich.

Równocześnie w literaturze możemy także odnaleźć teorię zróżnicowanych powiązań E. H. Sutherlanda, która dużą wagę przywiązuje do wzrastania w określonym środowisku wychowawczym (rodzinnym, rówieśniczym, szkolnym), co może w znacznym stopniu determinować określone zachowania człowieka. Poprzez obcowanie z osobami bliskimi przejawiającymi zachowania antyspołeczne stwarza się innym korzystne warunki do kształtowania pozytywnych przekonań dotyczących przemocy, dzięki czemu osoby te są bardziej skłonne do przejawiania zachowań antyspołecznych i przestępczych. Ważnym punktem opisywanej teorii jest nadwyżka wzorów negatywnych nad pozytywnymi w środowisku wychowawczym jednostki (Hirszel i in., 2010). Dzieci wychowywane w środowisku dysfunkcjonalnym są więc częściej narażone na stykanie się z zachowaniami niezgodnymi z normami społecznymi, co może stanowić istotny czynnik w przejawianiu przemocy rówieśniczej o charakterze bullyingu. 
B. Moon, H. Won-Hwang, J. D. McCluskey (2008), wyjaśniając zjawisko bullyingu w szkole, odwołują się do ogólnej teorii napięcia R. Agnewa (GST), zgodnie z którą jednostki, które doświadczyły fizycznego lub psychicznego maltretowania, są bardziej skłonne do podejmowania zachowań z obszaru przemocowych. Autorzy ponadto twierdzą, że w wyniku przeżywania negatywnych emocji (złości, gniewu) związanych z negatywnym, niewłaściwym traktowaniem, wrogością ze strony innych ludzi jednostka dąży do złagodzenia tych stanów i napięć poprzez stosowanie zachowań dewiacyjnych i przestępczych. Zgodnie z tą teorią zachowania negatywne spowodowane są odczuwaniem napięć wywołanych negatywnymi emocjami związanymi z zablokowaniem realizacji ważnych dla jednostki celów, na przeszkodzie których stoją inne osoby. R. Agnew twierdzi, że napięcie jest wynikiem niemożności unikania pewnych sytuacji trudnych, jest rezultatem niepowodzeń $\mathrm{w}$ osiąganiu pozytywnie wartościowanych celów, pozbawienia pozytywnej stymulacji. W związku z powyższym sprawca bullyingu, chcąc osiągnąć wyznaczony cel - dążąc do uzyskania określonej pozycji w grupie czy przynależenia do danej społeczności - będzie dopuszczał się zachowań niewłaściwych, by zredukować poziom napięcia wywołany wcześniejszymi niepowodzeniami w tym zakresie.

Wyjaśniając podłoże bullyingu, niektórzy badacze zjawiska wskazują na obecność deficytów w zakresie umiejętności społecznych, które znacząco mogą przyczyniać się do błędnego przetwarzania informacji społecznych. Autorzy opisywanego podejścia wywodzącego się z teorii społeczno-poznawczych twierdzą, że osoby niewłaściwie odczytują i interpretują sygnały płynące z zewnątrz, uznając je jako negatywne nastawienie wobec nich. „Patrząc pod kątem reprezentacji poznawczych i przetwarzania informacji, zakłada się przeważnie, że dzieci agresywne słabo rozumieją stany umysłu innych, mają niską samokontrolę i zdolność do oceny sytuacji, co prowadzi do zachowań impulsywnych i potencjalnie nasyconych przemocą" (Swearer, 2010, s. 56). W opozycji do tego modelu wyjaśniającego bullying są jednak J. Sutton i P. K. Smith, którzy, odnosząc się do teorii poznawczych, podkreślają, że sprawcy dokładnie wybierają ofiary przemocy, potrafiąc dokładnie ocenić ich pozycję w hierarchii klasy, słabości, cechy osobowości. Powyższe informacje o ofierze wykorzystują, stosując najczęściej bullying relacyjny przyjmujący formę plotkowania, manipulowania innymi, wyszydzania, wykluczania z grupy. Sprawcy mają więc dobrze rozwinięte umiejętności interpretacji zachowań i postaw innych osób, co wykorzystują do zaspokojenia egoistycznych potrzeb (Swearer, 2010).

Niezaprzeczalny jest także wpływ grupy na wspieranie i podtrzymywanie prześladowania. W środowisku szkolnym uczniowie uczą się od siebie pewnych zachowań społecznych poprzez zinternalizowanie norm grupy (Swearer i in., 2010, s. 42). Grupa zapewnia jednostce poczucie przynależności, jedności oraz odmienności od innych. Procesy zachodzące w grupie mają znamienny wpływ na funkcjonowanie jednostki w rolach oraz podejmowanie przez nią, bądź 
zaniechanie, określonych zachowań i przyjmowanie postaw. Na przyjmowanie roli ofiary, sprawcy lub świadka bullyingu znacząco wpływa pozycja zajmowana w grupie rówieśniczej oraz poziom akceptacji lub odrzucenia jednostki przez grupę (pozytywną lub negatywną).

Bullying jako zachowanie z obszaru patologii społecznej ujmowane jest z perspektywy ekologicznej, w której podkreśla się, że jest ono wynikiem zachodzących interakcji między czynnikami ryzyka. Zachowania bullyingowe nie są realizowane w izolacji, przyczyniają się do nich bowiem relacje zachodzące między jednostkami, relacje w środowisku rodzinnym, szkolnym, rówieśniczym, ale również ogólnie przyjęte i akceptowane normy społeczne. Podejście to zakłada, że na relacje między ofiarą i sprawcą wpływają cztery połączone ze sobą systemy: mikrosystem, mezosystem, egzosystem i makrosystem. Na poziomie indywidualnym możemy mówić o pewnych cechach sprawców i ofiar przyczyniających się do przyjmowania określonej roli w kontekście bullyingu. Mikrosystem stanowią oddziaływania najbliższych jednostce środowisk wychowawczych (rodzina, szkoła, grupa rówieśnicza). W szelkie czynniki regulujące funkcjonowanie środowisk ważnych socjalizacyjnie stanowią egzosystem (np. klimat społeczny instytucji, regulaminy, statut). Mezosystem odnosi się natomiast do interakcji między mikrosystemami. Ostatnim czynnikiem wymienianym przez autorów jest makrosystem obejmujący wszelkie wpływy społeczne i kulturowe oddziałujące na jednostkę (np. przekonania dotyczące stosowania przemocy w okresie adolescencji). Badacze Barboza i in., Salmivalli podkreślają, że ze względu na specyfikę bullyingu (szczególnie jego powtarzalność, zmienność form bullyingu wraz z wiekiem uczestników oraz stałość wiktymizacji ofiar) należy w podejściu ekologicznym uwzględnić także wymiar czasu nazwany chronosystemem (Pyżalski, 2012).

Problematyką bullyingu w środowisku więziennym zaczęto zajmować się na początku XXI w., jednakże ten obszar nie został dostatecznie zgłębiony. Podobnie jak w przypadku bullyingu w szkole podczas wstępnych badań nad bullyingiem w więzieniu uwaga badaczy koncentrowała się przede wszystkim na definiowaniu samego pojęcia oraz różnicowaniu go od tradycyjnego bullyingu. Następnie analizując zachowania określonych grup uczestniczących w bullyingu w środowisku więziennym, próbowano doszukać się powodów zachowań określonych uczestników bullyingu, co stanowiło impuls do poszukiwania teorii wyjaśniających ich reakcje na stosowaną przemoc. Uwaga badaczy szczególnie skoncentrowana była na grupie sprawców - ofiar.

Wyjaśniając występowanie bullyingu w więzieniu, autorzy odwołują się do kilku ujęć teoretycznych, między innymi do teorii szacowania skutków i zagrożenia (effect - danger ratio theory), rozwojowych teorii eskalacji agresji, modelu interakcyjnego (interactional model of proson bullying), stosowanego modelu reakcji strachu (applied fear response model - AFRM), (Monks, Coyne, 2012). 


\begin{tabular}{|c|}
\hline $\begin{array}{c}\text { MAKROSYSTEM } \\
\text { wpływ mediów/urbanizacja }\end{array}$ \\
\hline MEZOSYSTEM \\
\hline $\begin{array}{l}\text { POZIOM INDYWIDUALNY } \\
\text { - pewność siebie, } \\
\text { - poczucie bezradności, } \\
\text { - pochodzenie/rasa. }\end{array}$ \\
\hline $\begin{array}{l}\text { MIKROSYSTEM } \\
\text { sprawców i ofiar } \\
\text { - wsparcie emocjonalne ze strony rodziców, } \\
\text { - wsparcie emocjonalne ze strony rówieśników, } \\
\text { - obojętność nauczycieli. }\end{array}$ \\
\hline $\begin{array}{l}\text { MEZOSTSTEMY } \\
\text { sprawców i ofiar } \\
\text { - wsparcie rodziców w szkole, } \\
\text { - stresory szkolne. }\end{array}$ \\
\hline $\begin{array}{l}\text { EGZOSYSTEMY } \\
\text { sprawców i ofiar } \\
\text { - } \quad \text { atmosfera szkolna, } \\
\text { - pozaszkolne relacje rówieśnicze. }\end{array}$ \\
\hline CHRONOSYSTEM/wymiar czasu \\
\hline
\end{tabular}

Rysunek 2. Ekologiczny model czynników ryzyka powstawania bullyingu w szkole Źródło: J. Pyżalski, Agresja elektroniczna i cyberbullying..., s. 115

Pierwszym modelem wyjaśniającym powstawanie i trwałość bullyingu w więzieniu był interakcyjny model bullyingu, który znaczącą rolę przypisywał relacji czynników indywidualnych jednostki, jak również cech środowiska społecznego i fizycznego zakładu karnego. Model ten odrzuca koncentrowanie się jedynie na indywidualnych uwarunkowaniach bullyingu, a wskazuje także na cechy instytucji. Jako czynniki otoczenia społecznego, mające znaczenie dla występowania bullyingu w więzieniu, podaje się: kulturę więzienną, istnienie hierarchii władzy i dominacji, zachowania wspierające bullying, ale również negatywne ustosunkowanie się do bullyingu. Wśród cech fizycznych wymienia się: ograniczony dostęp do dóbr materialnych, środki bezpieczeństwa świadczące o pozytywnym ustosunkowaniu się do przemocy (Monks, Coyne, 2012, s. 164). 
Inne podejście prezentuje teoria szacowania skutków i zagrożenia, która w dużej mierze wyjaśnia bullying relacyjny, a odnosi się przede wszystkim do oceny przez sprawców możliwości wykrycia stosowanych przez nich działań bullyingowych (w kontekście zagrożenia). Sprawcy, analizując działania przemocowe z obszaru bullyingu, oceniają koszty, jakie może ponieść ofiara dręczenia (a są one zazwyczaj wysokie) oraz zagrożenie możliwością przyłapania ich na stosowaniu bullyingu. Ze względu na fakt, że działania zaburzające relacje międzyludzkie są trudne do zaobserwowania i wykrycia przez osoby niezaangażowane istnieje niewielkie prawdopodobieństwo zdemaskowania ich i jakiejkolwiek reakcji ze strony innych.

Odnosząc się ponownie do pośrednich form przemocy, które, jak podaje J. L. Ireland, występują w środowisku więziennym w znaczącej przewadze, porównując je z formami bezpośrednimi, należy przywołać rozwojowe teorie agresji. Zgodnie z ich założeniami uzupełnianie bezpośrednich form przemocy o formy pośrednie wzrasta z wiekiem uczestników. Dotyczy to szczególnie starszych adolescentów (Monks, Coyne, 2012). Jak się okazuje, chcąc uzyskać dominację w grupie, dzieci już pod koniec szkoły podstawowej „uciekają się” do metod antagonistycznych (Swearer, 2010).

Analizując zachowania ofiar bullyingu, badacze zjawiska odwołują się do reakcji walka - ucieczka i wyjaśniają je, przywołując stosowany model reakcji strachu. Model ten podkreśla odłożoną w czasie reakcję ucieczki i zapobieganie wiktymizacji. Stosowanie przemocy nie jest oceniane jedynie w kontekście walki, ale także jako ucieczka, która zostaje odroczona w czasie, ze względu na specyfikę instytucji zamkniętej, w której niemożliwa jest natychmiastowa ucieczka. Stosowanie bullyingu jest jednym ze sposobów na osiągnięcie przez więźnia odosobnienia (ucieczki odroczonej) poprzez stosowanie przemocy o charakterze bullyingu, co jest motywowane poczuciem strachu przed staniem się ofiarą bullyingu.

Reasumując, problematyka bullyingu jest coraz częściej podejmowanym przez naukowców zagadnieniem. Zainteresowanie tym tematem oscyluje już nie tylko wokół środowiska szkolnego. Kolejna fala badań dotyczy środowiska instytucji zamkniętej - bullyingu więziennego. Warto w badaniach nad bullyingiem znaleźć przestrzeń na zgłębienie tego obszaru poruszanego zagadnienia, ponieważ nie jest on dostatecznie zbadany, a znacząco różni się od bullyingu w środowisku szkolnym i zawodowym. Odnosząc się do konsekwencji bullyingu, należy rozpatrywać go jako problem społeczny, a nie tylko indywidualny czy problem danej instytucji.

\section{Bibliografia}

Aronson E. (red.), Człowiek - istota społeczna, Wydawnictwo Naukowe PWN, Warszawa 2002.

Cialdini R., Wywieranie wpływu na ludzi, GWP, Gdańsk 1996.

Dambach K. E., Mobbing w szkole. Jak zapobiegać przemocy grupowej?, GWP, Gdańsk 2003. 
Hennesey E., Guerin S., Przemoc i prześladowanie w szkole. Skuteczne przeciwdziałanie agresji wśród młodzieży, GWP, Gdańsk 2004.

Hirigoyen M. F., Molestowanie w pracy, W Drodze, Poznań 2003.

Hirszel K., Szczepanik R., Zbonikowski A., Modrzejewska D., Psychospołeczne uwarunkowania defaworyzacji dzieci i młodzieży, Difin, Warszawa 2010.

Ireland J., Archer J., Power Ch. L., Characteristics of Male and Female Prisoners Involved in Bullying Behavior, „Aggressive Behaviour” 2007, no 33.

Kliś M., Zachowania agresywne, a zagrożenia zdrowia psychicznego młodzieży szkolnej, Katedra Psychologii Akademii Pedagogicznej, Kraków 2000.

Kowalski R. M., Limber S. P., Agatson P. W., Cyberbullying. Bullying in the digital age, Blackwell Publishing, Ltd, 2008.

Le Bon G., Psychologia tlumu, Klon, Warszawa 1994.

Monks C. P., Coyne I., Przemoc i mobbing $w$ szkole, $w$ domu, w miejscu pracy, Wydawnictwo Naukowe PWN, Warszawa 2012.

Moon B., Won - Hwang H., McCluskey J. D., Causes of School Bullying, Empirical Test of a General Theory of Crime, Differential Association Theory, and General Strain Theory, „Crime \& Deliquency", no 10/2008.

Olweus D., Mobbing - fala przemocy w szkole. Jak ja powstrzymać?, Jacek Santorski \& Co, Warszawa 1998.

Piotrowski P. (red.), Przemoc i marginalizacja. Patologie społecznego dyskursu, Wydawnictwo Akademickie Żak, Warszawa 2004.

Pyżalski J., Agresja elektroniczna i cyberbullying jako nowe zachowania ryzykowne młodzieży, Oficyna Wydawnicza „Impuls”, Kraków 2012.

Smith P. K., Cowie H., Olafsson R. F., Liefooghe A. P. D., Definitions of Bullying: A Comparison of Terms Used, and Age and Gender Differences, in a Fourteen - Country Internacional Comparison, „Child Development”, no 4/2002, s. 1119-1133.

Smith P. K., Singre M., Hoel H., Cooper C. L., Victimization in the school and in the workplace: Are there any links?, „British Journal of Psychology”, no 94/2003.

South C. R., Wood J., Bullying in Prisons: the Importance of Perceived Social Status, Prisonization and Moral Disengagement, „Aggressive Behavior”, no 32/2006, s. 490-501.

Surzykiewicz J., Agresja i przemoc w szkole - uwarunkowania socjologiczne, MEN, Warszawa 2000.

Swearer S. M., Espelage D. L., Napolitano S. A., Przemoc rówieśnicza : zapobieganie i interwencje: skuteczne strategie dla szkót, Państwowa Agencja Rozwiązywania Problemów Alkoholowych, Warszawa 2010. 